\title{
Does India's Draft Mineral Policy Recognize and Implement Public Trust over Mineral Resources and Intergenerational Equity?
}

\author{
Kinnari BHATT*
}

Keywords: draft mineral policy, India, intergenerational equity, rights implementation mechanisms, sustainable development

\section{Introduction to the Draft Mineral Policy}

In 2018, the Indian government produced a draft mineral policy for non-fuel minerals (DMP). ${ }^{1}$ By analysing some interesting features of the policy concerning the grant of mining rights, the use of mineral receipts and the participation of local communities in land use decision making, this piece evaluates (i) how well the policy recognizes constitutional principles of public trust ${ }^{2}$ over mineral resources, ${ }^{3}$ intergenerational equity ${ }^{4}$ and sustainable development, (ii) the policy's lack of practical mechanisms for substantively implementing those principles, and (iii) suggests practical implementation mechanisms within the policy for advancing public trust and intergenerational equity.

The DMP extends an example of the tense balance India plays over attracting private concessionaires and implementing its constitutional duties on public trust and intergenerational equity. This is not a new dilemma. Local states have had been forced to rethink mining rights for public interest reasons, for example in Orissa Mining ${ }^{5}$

\footnotetext{
* Kinnari Bhatt is an English qualified solicitor and a postdoctoral researcher at Erasmus School of Law and the International Institute of Social Studies in the Netherlands.

1 Draft National Mineral Policy 2018 (India), http://www.indiaenvironmentportal.org.in/files/file/ draftnationalmineralpolicy2018.pdf (accessed 17 July 2018).

2 M.C. Mehta $v$ Kamal Nath \& Ors [1997] 1 SCC 388, 1996 Suppl. [10] SCR 12 embraced the public trust doctrine that 'the State is the trustee of all natural resources, which are by nature meant for public use and enjoyment'. Constitution of India 1950, art 39(b) requiring distribution of India's material resources to best serve the common good.

3 Reliance Natural Res., Ltd. v Reliance Indus., Ltd., (2010) I.N.S.C. 374, 95.

4 In India the principle of equality includes those who are unborn and waiting to be instantiated, ibid 94.

5 Orissa Mining Corporation v Ministry of Environment \& Forest \& Others (2014) SCC Writ Petition (Civ) No. 180 of 2011, although Odisha government has approved a long-term linkage policy permitting state-owned companies like Odisha Mining to enter into mining concessions with private companies with potentially exploitative consequences, Meera Mohanty, 'Odisha New Bauxite Linkage Policy to Benefit Vedanta', The Economic Times (21 February 2018), https://economictimes.indiatimes.com/industry/indl-goods/svs/metals-mining/odisha-new-bauxite-linkage-policy-tobenefit-vedanta/articleshow/63018502.cms (accessed 20 August 2018).
} distributed under the terms of the Creative Commons Attribution licence (http://creativecommons.org/licenses/by/4.0/), which permits unrestricted re-use, distribution, and reproduction in any medium, provided the original work is properly cited. 
concerning mining giant Vedanta's treatment of tribal peoples and in the 2018 Goa Foundation (GF) case. ${ }^{6}$ There, the Supreme Court quashed eighty-eight mining concessions due to Goa's failure to require license holders to apply for new environmental clearances upon second renewal. In Reliance ${ }^{7}$ the court ordered the renegotiation of private natural gas contracts unequivocally stating that private parties must be held accountable to the constitutional set-up on public trust and intergenerational equity.

The legal framework clearly has the tools for advancing sustainable mineral development. Yet, in practice, Indian mining development has more to do with power and economic incentive than public trust as the Common Cause $e^{8}$ case which triggered the DMP reminds us. Writs filed with the court demonstrated a mining scandal where companies had rapaciously illegally mined iron and manganese ore destroying the environment and lives of tribal peoples. The sheer scale of illegal mining violations has resulted in new legislative amendments seeking to clarify the definition of illegal mining and the related quantum of penalties ${ }^{9}$. Common Cause sent a message to Indian policy makers to give serious consideration to mining policy and governance structures that permit powerful companies to routinely subvert principles of sustainable development. The court directed the government to have a fresh look at the national mineral policy with regard to mineral development and conservation and to produce an effective, meaningful and implementable policy.

Against this background, the DMP has made some positive strides. Section 1 affirms the public trust principle that minerals and their value are held by the state for the common good, and section 10 supports intergenerational equity stating that the state must receive the full value of extracted minerals. Sections on sustainable development encourage a comprehensive view of land use supporting protection of forests and the environment. Such a seemingly enlightened position must, however, be scrutinized in a context of government inability to produce an inviolable forest area policy and the ongoing dilution of the rights of India's tribal people under the Forest Rights Act 2009 (India) to give or refuse consent to projects affecting their lands.

The DMP contains some innovative requirements for moratoriums on mining in ecologically fragile and biologically rich areas which go further than existing rehabilitation and resettlement laws that require community consent but extend no veto right to land owners against private and public private partnership land acquisition projects. The DMP has therefore created a space for communities to lobby government to create off-limit areas. The policy also reaffirms constitutional protection of indigenous and tribal populations stating that concessions must include assessments of the economic, cultural, environmental and social impact on tribal persons of land acquisition processes, but it fails to mention the principle of free, prior and informed

\footnotetext{
6 The Goa Foundation v M/s Sesa Sterlite Ltd. \& Ors (2018) SCC, SLP (C) No. 032138/2015.

7 Reliance, note $3,87$.

8 Common Cause v Union of India \& Ors (2017) SCC Writ Petition (Civ) No. 114 of 2014.

9 Meera Mohanty, Sarita Singh, 'Law Update in the Works to Clarify Illegal Mining', The Economic Times (21 March 2018) https://economictimes.indiatimes.com/industry/indl-goods/svs/metals-mining/law-update-in-the-worksto-clarify-illegal-mining/articleshow/63390464.cms (accessed 20 August 2018).
} 
consent. Crucially, assessments must be taken into account as early as possible in the decision-making process to ensure sustainable development in the mining sector. Provisions requiring stakeholders to take early warning measures are a welcome addition in light of Goa Foundation in which the court disparaged the state's hasty rejection of fresh environmental clearances and in light of previous critiques on the adverse effects on rights implementation of the late consideration of social issues in project design. ${ }^{10}$

In sum, the above provisions support the first part of the Supreme Court's direction for a policy encouraging conservation, mineral development and intergenerational equity. Whether they translate into the second half of the court's direction for an effective, meaningful and crucially, implementable policy that include for example, mechanisms to ensure community participation and the early consideration of resettlement issues, will now be evaluated.

\section{Gaps in Mechanisms for Rights Implementation}

Fundamental to the meaningful implementation of any sustainable mining policy is the process through which mining licences are granted. Goa Foundation concerned companies operating illegally without the environmental approvals required under the Mines and Minerals (Development and Regulation) Act 1957 (India) (MMDR). That case held that incentivizing private investment through rights of first refusal (which gives exploration licence holders a priority right to convert that licence into a mining licence), rather than an open auction system, is not contrary to constitutional principles of equality. Nonetheless, the case stated that there would be grounds for a community to challenge a decision not to hold a competitive auction on the basis of inadequate social and environmental considerations. Section 4.4 of the DMP prioritizes the grant of licences through rights of first refusal. Following Goa Foundation, the DMP could have included language prioritizing the grant of mineral rights through transparent auction systems. Such a policy mechanism would give teeth to the over-arching spirit of intergenerational equity and serving the common good that the policy purports to uphold.

Moreover, the DMP contains requirements for clearances to be streamlined and for related triggers at the higher state level in the event of delay in the approvals process. This is another troubling provision for its ambiguous prioritization of authorization regardless of the reasons for delay, which may arise from environmental or social concern. Furthermore, missing from the DMP are requirements for public disclosure of the decision-making processes for licence grant and renewal. Section 13 of the MMDR permits the government, through official gazette notification, to regulate the terms upon which mining licences are granted and renewed. A provision within the DMP requiring states to periodically provide this information for regular gazette would be a tangible means for transparent mineral development. If minerals are, as the policy states a

\footnotetext{
10 African Development Bank, 'The African Development Bank's Involuntary Resettlement Policy: Review of Implementation', African Development Bank (February 2015), https://esa.afdb.org/sites/default/files/SSS\%20-\% 20Involuntary\%20Resettlement $\% 20-\% 20 \mathrm{En} \% 20 \% 5 \mathrm{Bweb} \% 5 \mathrm{D}$.pdf (accessed 20 August 2018) discussing how time pressures in the project cycle resulted in the compression of consultation processes.
} 
'common good', information about the processes through which they are distributed is also a public good.

As noted, the DMP has done well in carving space for granting preferential rights for tribal communities in the form of no-go mining areas that will prevent resettlement in areas of high biodiversity. It does not, however, extend suggestions for practically implementing sustainable development in the majority of contexts in which resettlement will occur. These could look like specific requirements on companies to consult and negotiate with communities and obligations on companies to enter into agreements for land access and compensation/benefit sharing. ${ }^{11}$ It would be feasible to place the onus on prospective concessionaires to deliver (with their licence applications), guiding principles or heads of terms, to be made publically available, through which they plan to develop and implement full-blown agreements with communities. Such a provision would force companies to think about these measures early and would tangibly mobilize the early diligence principle. It would also provide communities with a tangible promise and supporting documents through which they could hold companies accountable in the event of future inaction.

Given that a major cause of weak or no resettlement monitoring or supervision is a lack of funds for resettlement programmes, the DMP has missed a chance for addressing the issue through concrete provisions that could further mobilize the early consideration principle; for example, requiring prospective concessionaires to deliver evidence of funds earmarked for resettlement within their project budgets or requirements that states set up decentralized offices with independent oversight that are dedicated to resettlement. Other methods by which the DMP could have included meaningful directions for early consideration of social issues is by requiring companies to lodge with the government information on the internal governance frameworks, if any, ${ }^{12}$ they have in place for considering land resettlement. More broadly, the DMP should have required companies applying for licences to provide periodically updated information on corporate structure, who within the company is responsible for environmental and social matters, and which companies will be undertaking construction and operation of the mine, with requirements for that information to be publicly available.

The last suggestion for the DMP draws on a similar critique from $\mathrm{GF}^{13}$ when it rightly states that the government has missed a real opportunity for setting up the mechanisms for a robust trust fund structure for the use of state mineral receipts ${ }^{14}$ Section 6.12 (b) contains a provision for the devolution of mining benefits directly to communities affected by mining projects through a Direct Mineral Foundation (DMF). This is a welcome addition as the payment of mineral receipts directly to citizens can be an

\footnotetext{
11 Benefit sharing agreements are standard requirements within indigenous peoples risk management policies of the International Finance Corporation, the Equator Principles and in domestic laws like the Australian Native Title Act 1993 (Cth).

12 If a company has no procedures the DMP would therefore require it to develop these processes in early project design.

13 'The Draft Mineral Policy is Designed to Promote Narrow Interests of Miners and their Lobbies', Counterview (7 February 2018) https://counterview.org/2018/02/07/the-draft-mineral-policy-is-designed-to-promote-narrow-interestsof-miners-and-their-lobbies/ (accessed 15 July 2018).

14 Joseph Bell and Teresa Faria, 'Critical Issues for a Revenue Management Law' in Macartan Humphreys, Jeffrey Sachs and Joseph Stiglitz (eds.), Escaping the Resource Curse (New York, Columbia University Press, 2007).
} 
effective measure for preventing the gross misallocation of public spending in mineralrich countries. However, that fund has no independent third party scrutiny and makes it the role of the government to monitor, review, allocate and spend implementation schemes under the fund: a position with a high corruption risk. A 2017 report $^{15}$ evaluating the implementation status of the DMF highlights the poor track record of even developing DMF plans, an administrative structure dominated by government officials with poor representation of local people and accountability deficits seen through a basic failure to register trust mechanisms appropriately and a lack of disclosure of the entities with which projects have been agreed.

The DMP could have given greater consideration to different types of private trust fund mechanisms. These include a national fund, like Norway's oil fund, the world's largest sovereign oil fund, set up to manage Norway's oil wealth for future generations by taking all the revenues the state receives from petroleum and investing it in financial assets abroad. A global south example is seen in the Chad Cameroon oil project, ${ }^{16}$ in which the revenue from oil constitutes the trust assets and a board of trustees manages receipts for the benefit of the general population. Given India's size, community-based structures like the Canadian Nanavut trust for oil receipts, might prove more effective to better address the needs of a large and diverse country. Benefits of local funds include their independence from central government, ability to determine their own priorities and produce democracy building at the community level.

The DMP missed the opportunity to stipulate headline requirements for a national or local fund, such as having a specific purpose, transparent and independent third party management and monitoring, a minimum threshold of community participation to minimize corruption, spending limits and perhaps a space for an international oversight board staffed by civil society representatives and monitored by an international financial institution, as occurred in Chad through the World Bank. The implementation of the private trust mechanism could be given teeth by the policy directing companies to require that the mechanism be part of the financing conditions for the project. The policy already recognizes that mining is an eligible activity for obtaining financial support from financial institutions and commits to taking steps to facilitate financing for exploration and mine development. It would therefore not be a big step for the DMP to require companies to tie practical implementation methods that promote intergenerational equity like the creation of a trust fund into their financing commitments.

Of course, trust funds are not silver bullets to sustainable development as without strong institutions to uphold them they are susceptible to political pressure and mismanagement, as was the case in Chad when the government elected to reassign portions of the oil fund for bureaucratic and security reasons. Without independent management the risk of money not trickling through becomes real but with the building blocks discussed above that could be built into the DMP, trust funds are a potentially powerful private mechanism that can deliver on the policy's sustainable and intergenerational equity compliant vision for mining.

\footnotetext{
15 Centre for Science and Environment, 'Direct Mineral Foundation (DMF) Status Report 2017' http://cdn.cseindia .org/attachments/0.06270600_1505300456_District-Mineral-Foundation-DMF-Report.pdf (accessed 20 August 2018).

16 Emeka Duruigbo, 'Managing Oil Revenues for Socioeconomic Development in Nigeria: The Case for CommunityBased Trust Funds' (2004) 30 North Carolina Journal of International Law and Commercial Regulation 121.
} 


\section{Conclusions on the Draft Mineral Policy}

This piece has evaluated the Indian draft mining policy and concludes that the government has offered a disappointingly light version of the rule of law in response to the Supreme Court's direction to produce a more effective, meaningful and implementable policy that supports mineral development and conservation. Although recognizing minerals as common goods and attaching intergenerational equity to mining development, the DMP fails, through a lack of effective implementation policies, to redress the governance imbalances within policy that favour powerful companies. On paper the DMP recognizes constitutional principles but crucially, it lacks the practical measures suggested in this piece, to counter the power of private companies and implement popular sovereignty over mineral resources. Facilitation of doing business is prioritized throughout the policy over any meaningful regulation of private interests that continue to loot the country of its national wealth. The DMP shows that in the field of mining development policy, the rule of law is informed by competing values on private property and public trust, and currently private interests take priority. This resonates with GF's critique $^{17}$ that whilst the policy makes some advances on the preceding one, it prioritizes the interests of miners and their lobbies. This piece has suggested some practical measures that could fill the implementation gap and begin to effect the substantive redistribution and democratization of mineral gains across communities and for future generations. The consequences of not addressing this implementation gap may yield adverse socioeconomic results as Indian people feel increasingly alienated by powerful companies whose property rights are prioritized over the peoples' constitutional right to benefit from common mineral resources. 